\title{
THE COMPOSITION OF EPIDIDYMAL PLASMA FROM THE CAUDA EPIDIDYMIDIS OF THE RAT
}

\author{
D. J. BACK, J. G. SHENTON AND T. D. GLOVER \\ Unit of Reproductive Biology, Life Sciences Building, \\ University of Liverpool, Liverpool L69 3BX
}

(Received 25th March 1974)

The composition of epididymal plasma has been described in the boar (Mann, 1964; Crabo, 1965), the bull (Crabo, 1965; Wales, Wallace \& White, 1966), the rabbit (Jones \& Glover, 1973) and the ram (Scott, Wales, Wallace \& White, 1963). In the rat, information on the subject is limited to measurements of ion concentrations (Levine \& Marsh, 1971) in fluid collected by micropuncture techniques and to scattered values obtained from post-mortem material (Conchie, Findlay \& Levvy, 1959; Dawson \& Rowlands, 1959; Marquis \& Fritz, 1965; Brooks, Hamilton \& Mallek, 1974). The composition of this fluid in any species is important in relation to sperm survival and would seem to be of particular interest in rodents due to its relatively viscous consistency. It would also seem preferable to obtain such fluid from living animals, and with a minimum of contamination. The present paper, therefore, reports on the chemical composition of epididymal plasma obtained from the intact cauda epididymidis of anaesthetized rats.

Twelve mature male rats (250 to $350 \mathrm{~g}$ ) of the Wistar strain were anaesthetized with urethane $(14 \% \mathrm{w} / \mathrm{v}$ in water $; 10.0 \mathrm{ml} / \mathrm{kg}$ intraperitoneally), and the testes were exposed through a scrotal incision. A 23-gauge needle attached to a length of polyethylene tubing ( $1 \mathrm{~mm}$ o.d., $0.5 \mathrm{~mm}$ i.d.) was inserted retrogradely into the ductus deferens, the other end of the tubing being attached to another needle and a syringe. The contents of the cauda epididymidis were collected by aspiration from both ductus deferentes aided by mild electrical stimulation $(0.5$ to $5.0 \mathrm{~V})$ of the smooth muscle of the cauda. Because of the viscous nature of the epididymal fluid in the rat, the caudal contents were expelled gradually over a period of 1 to $2 \mathrm{~min}$ and between 30 and $50 \mu \mathrm{l}$ of uncontaminated fluid were obtained.

The epididymal contents were transferred to microhaematocrit tubes and centrifuged at 12,000 $\mathrm{g}$ for $45 \mathrm{~min}$ in a microhaematocrit centrifuge (Hawksley Ltd). Increasing the time of centrifugation did not cause a significant decrease in the spermatocrit. The spermatocrit value and the volume of plasma collected were recorded. The plasma was separated and stored in polythene 'BEEM' capsules (TAAB Laboratories) at $-20^{\circ} \mathrm{C}$.

Eppendorf micro-test-tubes (V.A. Howe Ltd, London) were used for the microanalytical procedures. Volumes of 1 or $2 \mu \mathrm{l}$ were pipetted from Lang-Levy constriction pipettes (Shandon Southern) or from constriction pipettes made from glass tubing (o.d. $5 \mathrm{~mm}$; i.d. $3 \mathrm{~mm}$ ). Sodium and potassium were esti- 
mated by flame photometry using an EEL atomic absorption spectrophotometer (model 240). Glycerylphosphorylcholine (GPC) was determined by the periodate oxidation method of White (1959) as adapted for microlitre volumes by Crabo (1965). Glutamic oxaloacetic transaminase was determined at $546 \mathrm{~nm}$ by the method of Reitman \& Frankel (1957) as adapted by Boehringer in their test kit. Acid phosphatase and alkaline phosphatase were measured colorimetrically using p-nitrophenylphosphate as substrate (Boehringer test kits) and total protein by the Biuret reaction of Weichselbaum (1946) using $5 \%$ bovine serum albumin (Sigma, London).

The results are shown in Table $\mathbf{l}$ alongside previously estimated values for spermatocrit, sodium and potassium (Levine \& Marsh, 1971) and GPG (Brooks et al., 1974).

Table 1. The composition of epididymal plasma from the cauda epididymidis of the rat

\begin{tabular}{|c|c|c|c|c|}
\hline \multirow[b]{2}{*}{ Characteristic or constituent } & \multicolumn{2}{|c|}{ Present study } & \multicolumn{2}{|c|}{ Other recorded values } \\
\hline & Mean \pm S.E. & $\begin{array}{l}\text { No. of } \\
\text { rats }\end{array}$ & Mean $\pm S . E$. & $\begin{array}{c}\text { No. of } \\
\text { rats }\end{array}$ \\
\hline $\begin{array}{l}\text { Volume of plasma }(\mu \mathrm{l}) \\
\text { Spermatocrit }(\%) \\
\text { Sodium (mequiv./litre) } \\
\text { Potassium (mequiv./litre) } \\
\text { Glycerylphosphorylcholine }(\mathrm{mg} / 100 \mathrm{ml} \text { ) } \\
\text { Glutamic oxaloacetic } \\
\text { transaminase (i.u.) } \\
\text { Total protein (mg/100 ml) } \\
\text { Acid phosphatase (i.u.) } \\
\text { Alkaline phosphatase (i.u.) }\end{array}$ & $\begin{aligned} & 18 \cdot 86 \pm 0 \cdot 53 \\
& 54 \cdot 18 \pm 0 \cdot 83 \\
& 23 \cdot 94 \pm 2 \cdot 11 \\
& 50 \cdot 82 \pm 1 \cdot 47 \\
& 612 \cdot 0 \pm 16 \cdot 09 \\
& \\
& 2166 \cdot 0 \pm 162 \cdot 0 \\
& 3 \cdot 80 \pm 0 \cdot 04 \\
& 430 \cdot 0 \pm 7 \cdot 90 \\
& 47 \cdot 39 \pm 4 \cdot 50\end{aligned}$ & $\begin{array}{r}12 \\
12 \\
10 \\
12 \\
10 \\
10 \\
5 \\
12 \\
10\end{array}$ & $\begin{array}{r}54 \cdot 8 \pm 2 \cdot 6^{*} \\
20 \cdot 6 \pm 3 \cdot 0^{*} \\
55 \cdot 1 \pm 2 \cdot 3^{*} \\
1068 \cdot 0 \pm 49 \cdot 0^{\dagger} \\
- \\
= \\
=\end{array}$ & $\begin{array}{l}\overline{19 *} \\
14^{*} \\
14^{*} \\
12 \dagger \\
= \\
=\end{array}$ \\
\hline
\end{tabular}

i.u., International Units ( $\mu \mathrm{mol}$ substrate hydrolysed $/ \mathrm{min} / \mathrm{litre}$ at $37^{\circ} \mathrm{C}$ ).

* Data from Levine \& Marsh (1971).

$\dagger$ Data from Brooks et al. (1974).

It is evident that values obtained for sodium and potassium compare favourably with those obtained by Levine \& Marsh (1971), but the $1: 2 \cdot 1$ ratio of sodium to potassium found in the present study differs from the approximate 1:1 ratios reported by previous workers for boars (Mann, 1964; Crabo, 1965), bulls (Crabo \& Gustafsson, 1964; Wales et al., 1966), rabbits (Jones \& Glover, 1973) and rams (Scott et al., 1963; Jones, 1973). In the rat, therefore, it appears that the concentration of potassium ions in the fluid from the cauda epididymidis is relatively higher than that of other animals examined. Levine \& Marsh (1971) reported that between the caput and the cauda epididymidis the sodium ion concentration decreased by 91 mequiv./litre, whilst the potassium ion concentration increased by 39 mequiv./litre. They suggested that the rising potassium concentration could be accounted for chiefly by removal of water, which follows the presumed active reabsorption of sodium ions, although there may also be a contribution from epithelial secretion into the lumen.

The level of acid phosphatase in rat epididymal plasma is approximately the same as that found by Jones (1973) in the epididymal plasma of the 
hamster. The level of alkaline phosphatase, however, is markedly lower than values reported for the rabbit (Jones \& Glover, 1973), the ram (Murdoch \& White, 1968; Jones, 1973) and the hamster (Moniem, 1972). Histochemical studies on the rat epididymis have shown that acid phosphatase is present in the epithelial cells lining the duct (Martan, 1969; Moniem, 1972) although it is not clear whether or not the enzyme is sequestered into the lumen and contributes to the phosphatase found in the epididymal plasma (Moniem \& Glover, 1972). Maneely (1955), Martan \& Risley (1963) and Moniem (1972) have claimed that there is no demonstrable alkaline phosphatase activity in the epithelial cells of the rat epididymis and that the luminal contents are nonreactive. The present finding confirms this.

We obtained lower values for GPG concentration than Brooks et al. (1974), but they dissected out the epididymis before collecting the fluid and this difference in technique may account for the discrepancy.

The presence of GPC in epididymal plasma is well documented in a variety of species (Dawson, Mann \& White, 1957; Dawson \& Rowlands, 1959; Scott et al., 1963; Crabo, Gustafsson, Bane, Meschaks \& Ringmar, 1967) and it is generally regarded as being a specific secretory product of the epididymis itself. The precise biological significance of GPC in the lumen of the epididymis, however, is not yet clear.

This work was supported by a grant from the World Health Organization.

\section{REFERENCES}

Brooks, D. E., Hamilton, D. W. \& Mallek, A. H. (1974) Carnitine and glycerylphosphorylcholine in the reproductive tract of the male rat. F. Reprod. Fert. 36, 141.

Conchie, J., Findlay, J. \& Levvy, G. A. (1959) Mammalian glycosidases. Distribution in the body. Biochem. 7. 71, 318.

Grabo, B. (1965) Studies on the epididymal content in bulls and boars. Acta vet. scand. 6, Suppl. 5.

GRABo, B. \& Gustafsson, B. (1964) Distribution of sodium and potassium and its relation to sperm concentration in the epididymal plasma of the bull. $\mathcal{F}$. Reprod. Fert. 7, 337.

Crabo, B., Gustafsson, B., Bane, A., Meschaks, P. \& Ringmar, J. E. (1967) The concentration of sodium, potassium, calcium, inorganic phosphate, protein and glycerylphosphorylcholine in the epididymal plasma of bull calves. F. Reprod. Fert. 13, 589.

Dawson, R. M. G., MANN, T. \& Whrte, I. G. (1957) Glycerylphosphorylcholine and phosphorylcholine in semen and their relation to choline. Biochem. 7. 65, 627.

Dawson, R. M. G. \& Rowlands, I. W. (1959) Glycerylphosphorylcholine in the male reproductive organs of rats and guinea pigs. Q. Jl exp. Physiol. 44, 26.

Jones, R. (1973) Studies on the composition of epididymal plasma. Ph.D. thesis, University of Liverpool.

Jones, R. \& Glover, T. D. (1973) The collection and composition of epididymal plasma from the cauda epididymidis of the rabbit. F. Reprod. Fert. 34, 395.

Levine, N. \& Marsh, D. J. (1971) Micropuncture studies of the electrochemical aspects of fluid and electrolyte transport in individual seminiferous tubules, the epididymis and vas deferens in rats. F. Physiol., Lond. 213, 557.

Maneely, R. B. (1955) The distribution of polysaccharide complexes and of alkaline glycerophosphatase in the epididymis of the rat. Acta anat. 24, 314.

Mann, T. (1964) The Biochemistry of Semen and of the Male Reproductive Tract. Methuen, London.

Martan, J. (1969) Epididymal histochemistry and physiology. Biol. Reprod., Suppl. 1, 134.

Martan, J. \& Risley, P. L. (1963) The epididymis of mated and unmated rats. F. Morph. 113, 1.

MARQUIS, N. R. \& FrITz, I. B. (1965) Effects of testosterone on the distribution of carnitine, acetylcarnitine, and carnitine acetyltransferase in tissues of the reproductive system of the male rat. 7. biol. Chem. 240, 2197.

Moniem, K. A. (1972) Some histochemical features of the mammalian epididymis. Ph.D. thesis, University of Liverpool. 
Moniem, K. A. \& GLover, T. D. (1972) Comparative histochemical localization of lysosomal enzymes in mammalian epididymides. $\mathcal{F}$. Anat. 111, 437.

Murdoch, R. N. \& White, I. G. (1968) Studies on the distribution and source of enzymes in mammalian semen. Aust. F. biol. Sci. 21, 483.

Rritman, S. \& Frankel, S. (1957) A colorimetric method for the determination of serum glutamic oxalacetic and glutamic pyruvic transaminases. Am. F. clin. Path. 28, 56.

Scott, T. W., Wales, R. G., Wallace, J. G. \& White, I. G. (1963) Composition of ram epididymal and testicular fluid and the biosynthesis of glycerylphosphorylcholine by the rabbit epididymis. 7. Reprod. Fert. 6, 49 .

Wales, R. G., Wallace, J. G. \& WhIte, I. G. (1966) Gomposition of bull epididymal and testicular fluid. F. Reprod. Fert. 12, 139.

WeichSELBAuM, T. E. (1946) An accurate and rapid method for the determination of proteins in small amounts of blood serum and plasma. Am. F. clin. Path. tech. Suppl. 10, 40.

Whrte, I. G. (1959) Studies on the estimation of glycerol, fructose and lactic acid with particular reference to semen. Aust. J. exp. Biol. med. Sci. 37, 441. 